\title{
$10 / 18.948501$
$10^{-18}$ CONTRACTOR REPORT
}

SAND $94-2105$

Unlimited Release

UC-721

\section{Disposal Configuration Options for Future Uses of Greater Confinement Disposal at the Nevada Test Site}

\section{Laura Price}

Science Applications International Corporation 2100 Air Park Road SE

Albuquerque, NM 87106

Prepared by Sandia National Laboratories Albuquerque, New Mexico 87185 and Livermore, California 94550 for the United States Department of Energy under Contract DE-AC04-94AL85000

Printed September 1994 
Issued by Sandia National Laboratories, operated for the United States Department of Energy by Sandia Corporation.

NOTICE: This report was prepared as an account of work sponsored by an agency of the United States Government. Neither the United States Government nor any agency thereof, nor any of their employees, nor any of their contractors, subcontractors, or their employees, makes any warranty, express or implied, or assumes any legal liability or responsibility for the accuracy, completeness, or usefulness of any information, apparatus, product, or process disclosed, or represents that its use would not infringe privately owned rights. Reference herein to any specific commercial product, process, or service by trade name, trademark, manufacturer, or otherwise, does not necessarily constitute or imply its endorsement, recommendation, or favoring by the United States Government, any agency thereof or any of their contractors or subcontractors. The views and opinions expressed herein do not necessarily state or reflect those of the United States Government, any agency thereof or any of their contractors.

Printed in the United States of America. This report has been reproduced directly from the best available copy.

Available to DOE and DOE contractors from Office of Scientific and Technical Information PO Box 62

Oak Ridge, TN 37831

Prices available from (615) 576-8401, FTS 626-8401

Available to the public from

National Technical Information Service

US Department of Commerce

5285 Port Royal Rd

Springfield, VA 22161

NTIS price codes

Printed copy: A03

Microfiche copy: A01 


\section{DISCLAIMER}

Portions of this document may be illegible in electronic image products. Images are produced from the best available original document. 


\title{
DISPOSAL CONFIGURATION OPTIONS FOR FUTURE USES OF GREATER CONFINEMENT DISPOSAL AT THE NEVADA TEST SITE*
}

\author{
Laura Price \\ Science Applications International Corporation \\ 2100 Air Park Road SE \\ Albuquerque, NM 87106
}

\begin{abstract}
The U.S. Department of Energy (DOE) is responsible for disposing of a variety of radioactive and mixed wastes, some of which are considered special-case waste because they do not currently have a clear disposal option. The DOE's Nevada Field Office contracted with Sandia National Laboratories to investigate the possibility of disposing of some of this special-case waste at the Nevada Test Site (NTS). As part of this investigation, a review of near-surface and subsurface disposal options that was performed to develop alternative disposal configurations for special-case waste disposal at the NTS. The criteria for the review included (1) configurations appropriate for disposal at the NTS; (2) configurations for disposal of waste at least $100 \mathrm{ft}$ below the ground surface; (3) configurations for which equipment and technology currently exist; and (4) configurations that meet the special requirements imposed by the nature of special-case waste. Four options for subsurface disposal of special-case waste are proposed: mined consolidated rock, mined alluvium, deep pits or trenches, and deep boreholes. Six different methods for near-surface disposal are also presented: earth-covered tumuli, above-grade concrete structures, trenches, below-grade concrete structures, shallow boreholes, and hydrofracture. Greater confinement disposal (GCD) in boreholes at least $100 \mathrm{ft}$ deep, similar to that currently practiced at the GCD facility at the Area 5 Radioactive Waste Management Site at the NTS, was retained as the option that met the criteria for the review. Four borehole disposal configurations are proposed with engineered barriers that range from the native alluvium to a combination of gravel and concrete. The configurations identified will be used for system analyses that will be performed to determine the disposal configurations and wastes that may be suitable candidates for disposal of special-case wastes at the NTS.
\end{abstract}

* Work performed under contract No. 67-1811 for Safety and Risk Assessment Department, Sandia National Laboratories, Albuquerque, NM. 


\section{ACKNOWLEDGEMENTS}

The author would like to thank Pat Rowe of Reynolds Electrical and Engineering Company, Inc., Mr. David Thomson of Sandia National Laboratories (SNL), and Mike Butler of Lawrence Livermore National Laboratories for providing information regarding the technology available for excavating in alluvium. The assistance of Tom Baer (GRAM, Inc.), Steve Conrad (SNL), Paul Davis (SNL), Felicia Durán (GRAM, Inc.), David Gallegos (SNL), and Harlan Stockman (SNL) in reviewing this document and addressing comments is also very much appreciated. Finally, the author would like to thank Joe Ginanni of DOE's Nevada Operations Office, Stu Rawlinson and Dennis Gustafson of Raytheon Service Nevada, and the Special Projects Section of Reynolds Electrical and Engineering Company, Inc., for reviewing this report. 


\section{CONTENTS}

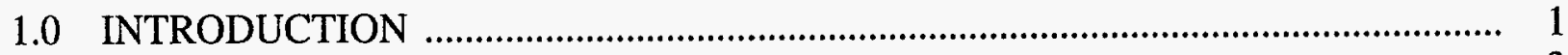

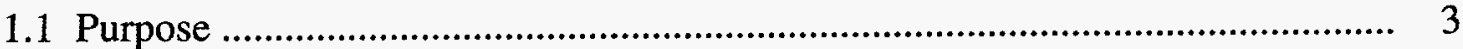

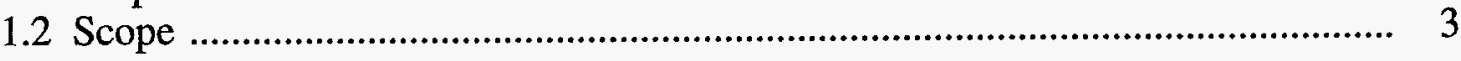

2.0 POSSIBLE DISPOSAL CONFIGURATIONS AT THE NTS …………………......... 7

2.1 Configurations Considered ............................................................................... 7

2.1.1 Subsurface Disposal ........................................................................... 7

2.1.2 Near-Surface Disposal ...................................................................... 9

2.2 Boreholes and their Options ............................................................................... 12

2.2 .1 Borehole Depth ............................................................................... 12

2.2.2 Borehole Diameter ........................................................................ 13

2.2 .3 Borehole Location ............................................................................ 13

2.2.4 Borehole Spacing .............................................................................. 14

2.2.5 Physical Barriers .................................................................................... 14

2.2.6 Chemical Barriers ......................................................................... 16

3.0 DISPOSAL CONFIGURATIONS TO BE CONSIDERED IN THE SYSTEM

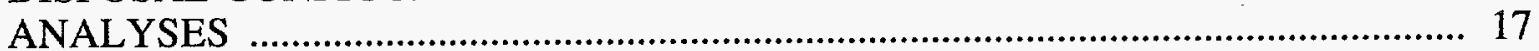

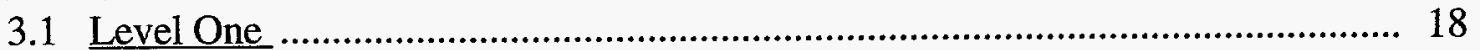

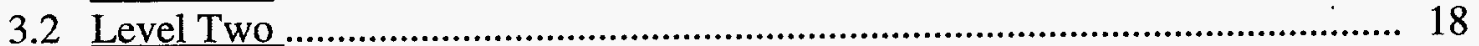

3.3 Level Three

3.4 Level Four …….............................................................................................. 20

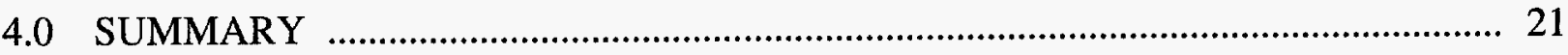

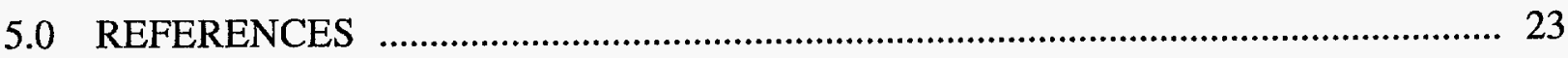

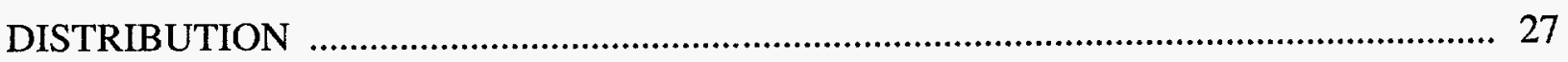

\section{TABLE}

Table 1: Summary of Disposal Options Examined 


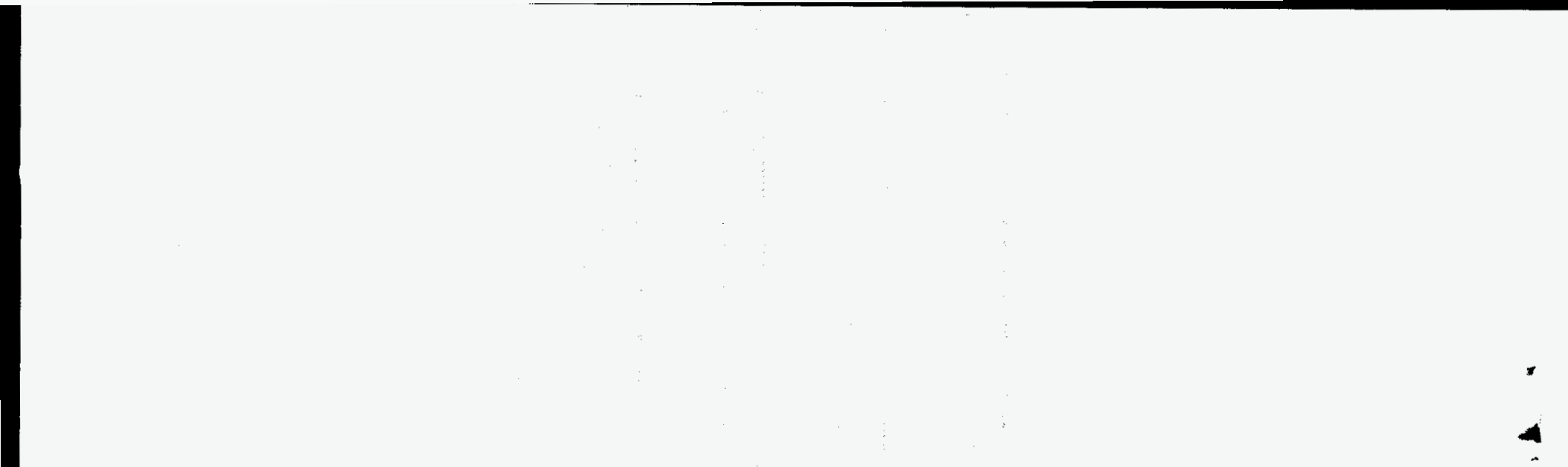




\subsection{INTRODUCTION}

The United States Department of Energy (DOE) is responsible for disposing of radioactive waste that it produces as well as certain wastes produced by commercial generators (i.e., nuclear power plants) [NWPA, 1982]. These wastes fall into one of five categories: byproduct, naturally occurring, and accelerator-produced radioactive material; transuranic (TRU) waste; high-level waste (HLW); spent nuclear fuel; and low-level waste (LLW). Byproduct material consists of the radioactive wastes generated in the process of mining uranium to produce nuclear fuel (i.e., uranium or thorium tailings). Naturally occurring and accelerator-produced radioactive material is material that is produced in a charged particle accelerator or that can be considered naturally occurring and is not source, special nuclear, or byproduct material. TRU waste is DOE-titled radioactive waste, without regard to source or form, contaminated with alpha-emitting transuranium isotopes (i.e., atomic number greater than 92) that have half-lives greater than 20 years in concentrations greater than 100 nanocuries/gram [DOE, 1992]. HLW is the radioactive waste that results from the reprocessing of spent fuel. Spent fuel consists of the fuel rods removed from a nuclear reactor following irradiation, the constituent elements of which have not been separated by reprocessing. LLW is radioactive waste that is not byproduct material, transuranic or high-level waste, or spent fuel [DOE, 1988].

Current or planned disposal practices for the above types of waste are as follows. Byproduct, naturally occurring, and accelerator-produced radioactive materials have historically been disposed of on-site by placing an earthen cover over the mounded tailings [UMTRCA, 1978; DOE, 1988]. By law, defense TRU waste is to be disposed of in the Waste Isolation Pilot Plant (WIPP) near Carlsbad, New Mexico [NEAA, 1980], and HLW and spent fuel, either commercially generated or generated by defense activities, are to be disposed of in the proposed HLW repository [NWPA, 1982]. Yucca Mountain in Nevada is currently being investigated by the DOE as the HLW repository site. Traditionally, LLW has been disposed of using near-surface burial techniques (e.g., shallow trenches, earth-mounded concrete bunkers) at various DOE and commercial sites around the country [DOE, 1988].

Most of the waste that the DOE is responsible for can be disposed of using the methods mentioned above. However, there are some wastes that cannot be disposed of in this manner. Such wastes are termed special-case wastes and need alternative disposal methods or need to be treated so they can be disposed of using one of the disposal practices mentioned above. A waste can be classified as special-case for a variety of reasons. Some of these reasons are that the waste is too big to be acceptable to the disposal facility and cannot be reduced in size, has radionuclide concentrations that exceed site-specific limits, contains hazardous waste prohibited by the waste acceptance criteria, must be handled remotely because of high gamma radiation levels, or is classified.

Special-case waste is discussed in more detail by Price and Durán [1994]. In summary, Price and Durán defined five categories of special-case radioactive wastes that are special-case wastes and specified "typical" radionuclide concentrations per $\mathrm{m}^{3}$ of waste. These categories are (1) transuranic, (2) fission products, (3) activation products, (4) volatile or mobile, and (5) sealed sources. The radionuclides belonging to each group share a common characteristic (e.g., alphaemitters, heat generators, exist in vapor phase), and we believe that the special-case wastes generated by the DOE can be described as consisting of radionuclides from one or more of these groups. There is some overlap of radionuclides between groups (e.g., $238 \mathrm{Pu}$ is transuranic as well as being used in sealed sources), but this should not present any problems. Price and Durán also 
discuss categories of special-case mixed waste which, because of the lack of available treatment capacity, may also be candidates for GCD.

One alternative to typical LLW disposal methods that can be used to dispose of some of the DOE's special-case waste is called Greater Confinement Disposal (GCD). This method of disposal has been used by the DOE to dispose of waste at the Nevada Test Site (NTS) and at the Savannah River Plant (SRP). As presently practiced at these sites, GCD consists of placing wastes in the bottom of a borehole and covering the wastes with concrete, clay, soil, gravel, or sand. The selection of cover material has depended on the site [Trevorrow and Schubert, 1989]. At the SRP, a humid site, the boreholes are $10 \mathrm{ft}$ in diameter and $34 \mathrm{ft}$ deep. The bottom of the hole is filled with $3.3 \mathrm{ft}$ of gravel and a 20 -foot tall fiberglass liner is grouted in place above the gravel. Waste is emplaced in the liner and all spaces between the packages are filled with grout. Once the liner is filled, the hole is backfilled with layers of concrete, clay, and soil. At the NTS, an arid site, the boreholes are 10 to $12 \mathrm{ft}$ in diameter and $120 \mathrm{ft}$ deep. Waste is emplaced in the bottom $50 \mathrm{ft}$ of each borehole and the top $70 \mathrm{ft}$ is backfilled with native alluvium that has been sifted to remove large cobbles. Alluvium is mounded on top of the hole and it is monitored to mitigate the effects of subsidence.

Greater confinement disposal at the NTS was first developed in the early 1980s as a method of disposing of LLW that was not suitable for near-surface disposal (e.g., highly mobile wastes such as ${ }^{3} \mathrm{H}$ and thermal wastes such as encapsulated ${ }^{90} \mathrm{Sr}$ ). Subsequently, classified TRU wastes were disposed of using GCD, as were ${ }^{3} \mathrm{H},{ }^{238} \mathrm{U},{ }^{90} \mathrm{Sr},{ }^{137} \mathrm{Cs}$, and ${ }^{60} \mathrm{Co}$. Based on recent compliance assessments, the GCD boreholes at the NTS are likely to be protective of human health and the environment [Price et al., 1993; Baer et al., 1993]. Therefore, the DOE is interested in knowing if the NTS would be a suitable site for disposing of additional special-case waste using GCD. The DOE has asked Sandia National Laboratories to perform system analyses to study this question.

Before system analyses could be performed, however, a few issues had to be decided. First, the characteristics of special-case waste that could be destined for GCD at the NTS had to be defined; this has been done [Price and Durán, 1994]. Second, we wanted to expand on the present GCD concept by examining a variety of GCD-type disposal configurations (e.g., using engineered barriers or not using boreholes). These GCD-type disposal configurations, which will be used in the system analyses, are documented in this report. Third, once the characteristics of special-case waste and potential GCD-type disposal configurations have been defined, the next step will be to define the criteria by which the various disposal options for different waste types will be evaluated. These criteria will be documented in a report that follows the present report on GCD-type disposal configurations. Once these three steps have been completed, the system analyses will be conducted. The system analyses will examine whether the waste identified in the first subtask and disposed of in disposal configurations identified in the second subtask meet the criteria outlined in the third subtask. The system analyses will be similar to a performance assessment in that we will examine the long-term safety of these disposal configurations, but we will also examine such factors as cost and worker safety. The results of these analyses should guide the development of waste acceptance criteria for the disposal of special-case waste at the NTS and should contribute to the basis for writing a Technical Alternatives Document, as required by the National Environmental Policy Act [NEPA, 1978].

The following sections give the purpose and scope of this report, respectively. Chapter 2 discusses disposal configuration options, Chapter 3 gives the options that will be used in the system analyses, and Chapter 4 contains a summary. 


\subsection{Purpose}

The purpose of this report is to identify GCD-type disposal configurations that could be used to dispose of special-case wastes at the NTS so that system analyses can be performed to determine, from a technical viewpoint, which wastes could be disposed of at the NTS. It is not the purpose of this report to design an optimal GCD-type disposal system, nor is it the purpose of this report to conduct a systematic evaluation of disposal options. In this report, we are "brainstorming" on paper. Some special-case wastes require new disposal practices because the waste cannot be disposed of using existing disposal techniques. We attempted to identify some new disposal configurations that might be feasible at the NTS for special-case waste.

The system analyses will first examine whether special-case wastes can be disposed of safely at the NTS using the disposal configurations outlined in this report. That is, performance-assessment type analyses will be conducted for the special-case wastes and disposal configurations identified in the first two subtasks to see which, if any, special-case wastes can be safely disposed of at the NTS and the degree of isolation required. Those disposal options that are shown to be safe will then be compared against the other criteria identified in the third subtask (e.g., cost, worker safety), and the options will be ranked according to how well each option meets the criteria. The system analyses will provide guidance to the DOE concerning the types of waste that can be disposed of at the NTS using GCD-type disposal methods and what the optimal disposal method is. The results cannot be used to demonstrate compliance with environmental regulations.

Finally, the system analyses will consider the uncertainties involved in modeling the performance of the various disposal configurations in much the same way that previous performance assessments have considered uncertainty [Baer et al., 1993; Price et al., 1993]. The effects of likely future events and processes will be considered in the system analyses. Although these events and processes have not yet been identified, the effects of some (such as erosion, increased recharge from climate change, and human intrusion) will be considered in selecting the disposal configurations that will be used in the system analyses. For example, the distance from the bottom of the waste to the water table, although not a concern given the current low recharge rate [Conrad, 1993], may be a concern if the recharge rate were to increase significantly as a result of a change in climate. Therefore, the distance from the bottom of the waste to the water table will be allowed to vary to account for a possible increase in recharge.

\section{$1.2 \underline{\text { Scope }}$}

The disposal configuration options that we could consider were limited by a number of constraints. The first constraint was that disposal was to be at the NTS. One reason for this constraint is that the federal government owns the NTS, which is already radioactively contaminated from weapons testing, so developing a disposal facility at the NTS is less complicated than developing one at a location that is not currently owned by the federal government. A second reason is that the system analyses will require many of the same data and models required by the performance assessments currently in progress for the existing GCD boreholes at the NTS. We will have access to those data and models, minimizing the amount of additional data needed and the need for model development. Not limiting disposal to the NTS, for the purposes of this study, would require a significant amount of effort in terms of data collection and model development. It is important to note that the DOE controls properties that are not in Nevada but are similar to the NTS in that they

are arid and have similar hydrogeologic settings. Some of these other sites may be suitable candidates for GCD-type disposal of special-case wastes and could be studied for that purpose. 
The second constraint was that disposal configurations had to accommodate the disposal of waste at least $100 \mathrm{ft}(30 \mathrm{~m})$ below the ground surface. This constraint came about because most specialcase wastes are not suitable candidates for near-surface disposal [Price and Durán, 1994]. Both the Nuclear Regulatory Commission (NRC) [NRC, 1993] and the DOE [DOE, 1988] have defined near-surface disposal as disposal in the upper $100 \mathrm{ft}(30 \mathrm{~m})$ of the earth's surface. The NRC has stated explicitly that certain low-level wastes whose radionuclide concentrations exceed specific limits (i.e., Greater than Class $\mathrm{C}$ waste) are not suitable for near-surface disposal [NRC, 1993]. The DOE has not made such a statement explicitly, but it does require low-level wastes which would be classified as Greater than Class C (if they were subject to the NRC classification guidelines) to be handled as special cases [DOE, 1988]. Many of the wastes thought to be potentially destined for greater confinement disposal at the NTS have radionuclide concentrations exceeding Class C limits [Price and Durán, 1994]; therefore, we are considering only those options that are not near-surface disposal. It is recognized that $\mathrm{GCD}$, as previously practiced at the NTS, involves disposal of waste within $70 \mathrm{ft}$ of the ground surface, a departure from the 100-ft constraint outlined above. However, it is appropriate to follow the guidelines that are currently in the regulations, rather than rely on past disposal practices to provide guidance.

A third constraint was that we considered only those disposal configurations for which equipment and technology currently exist. The purpose of this constraint was to provide some insight into whether currently existing technology and equipment can be used to develop a disposal system for special-case waste. Disposing of special-case waste without having to develop new technologies and equipment would likely result in significant cost savings. While formal cost analyses were not performed, the efficiency of a disposal configuration was a consideration in deciding on GCD-type configurations.

A fourth constraint is that disposal configurations must meet the special requirements that are imposed by the nature of special-case waste. For example, the disposal configuration must be capable of remaining open for several years and accepting waste on an intermittent basis because special-case waste frequently is not generated or shipped on a regular basis. The configuration must be capable of disposing of thermal waste and waste having high surface radiation dose rates without posing unacceptable risks to personnel. Also, it must be capable of disposing of classified waste and large objects, as well as mixed or hazardous waste.

Finally, one very important assumption we made was that GCD boreholes are not injection wells. The State of Nevada maintains that GCD boreholes are Class IV injection wells, which are prohibited by the Environmental Protection Agency (EPA) in 40 CFR 144.13 and by the State of Nevada [NAC, Chapter 445]. Class IV injection wells are wells used to dispose of hazardous or radioactive waste into or above a formation which within one-quarter (1/4) mile of the well contains an underground source of drinking water [40 CFR 144.6]. The EPA has studied this issue and has concluded that "...the underground disposal of containerized radioactive waste in geologic repositories subject to the part 191 standards does not constitute underground injection within the meaning of the Safe Drinking Water Act (SDWA) or EPA's regulations governing the Underground Injection Control (UIC) program" [EPA, 1993]. The effect that the EPA's statement will have on Nevada's opinion that the GCD boreholes are injection wells is not known at this time. It is possible that the State of Nevada could still consider GCD boreholes to be Class IV injection wells and, therefore, prohibited under the State of Nevada's UIC Program. This is a critical issue, as will be seen, because all of the possible disposal configurations involve boreholes. 
It should be noted that, to provide substantive equivalence between 40 CFR 191 and the SDWA, the EPA has reserved final action on the ground water protection requirements with respect to disposal systems located above or within a formation which within one-quarter mile of the disposal system contains an underground source of drinking water. The EPA will address this category of disposal system when it establishes disposal standards for Yucca Mountain, sometime late in 1995. The present GCD boreholes and, most likely, any future GCD boreholes fall into this category, meaning that ground water protection requirements will not be established for GCD boreholes until 1995, at the earliest. 


\subsection{POSSIBLE DISPOSAL CONFIGURATIONS AT THE NTS}

In the course of coming up with different disposal configurations, a number of configurations were considered, examined to see if they were consistent with the scope of this subtask (see Section 1.2), and, if they were not consistent, then discarded. In the end, all of the remaining options involved boreholes. Those configurations that were considered are discussed in Section 2.1, and the various options that can be used with boreholes are discussed in Section 2.2.

\subsection{Configurations Considered}

Radioactive waste disposal systems that either currently exist or are in the planning stages around the world can be divided into two categories: subsurface disposal and near-surface disposal. Generally, only LLW is disposed of in near-surface disposal facilities, while spent fuel, HLW, TRU waste, and LLW can be disposed of in subsurface disposal facilities. As mentioned above, in the U. S., near-surface disposal has been defined by the NRC [NRC, 1993] and the DOE [DOE, 1988] as disposal within the upper $100 \mathrm{ft}(30 \mathrm{~m})$ of the earth's surface, so subsurface disposal can be thought of as disposal at depths of $100 \mathrm{ft}$ or greater. In the following paragraphs, various radioactive waste disposal configurations that either exist or are in the planning stages are discussed in terms of whether they are good candidates for GCD at the NTS. Table 1 summarizes the disposal configurations examined, whether each was a good candidate for GCD at the NTS (i.e., whether it should be eliminated from further consideration or retained), and the reason for the decision.

\subsubsection{Subsurface Disposal}

One subsurface disposal configuration considered as a method of disposing of special-case waste at the NTS was mined cavities in consolidated rock. These cavities can be excavated solely for the purpose of waste disposal or can be the result of mineral extraction [Trevorrow and Schubert, 1989]. This subsurface method of radioactive waste disposal has been pursued by Czechoslovakia (Richard mine), Finland (Olkiluoto), Germany (Morsleben and Konrad), Sweden (Forsmark), and Switzerland for disposal of low- and intermediate-level waste. The depths of these disposal facilities, some of which are still in the conceptual stage, range from $200 \mathrm{ft}(60 \mathrm{~m})$ below the ground surface (Olkiluoto and Forsmark) to $4300 \mathrm{ft}(1300 \mathrm{~m})$ below the ground surface (Konrad). Most of these disposal concepts employ multiple barriers such as waste form, waste package, concrete, clay, and crushed and ground host rock [IAEA, 1992]. Disposal of spent fuel and HLW in mined cavities in consolidated rock has also been pursued by France, Switzerland, Sweden, Canada, the U.S., Finland, Japan, Germany, the Netherlands, and the U.K. [Apted et al., 1993]. Most of these countries are still selecting sites, performing site characterization studies, or designing the waste packages and other barriers for disposal of spent fuel and HLW.

This disposal configuration, although it appears to be sound technically and would readily permit the disposal of special-case waste at depths exceeding $100 \mathrm{ft}$, was eliminated because considering it would amount to duplicating the effort that is already underway at Yucca Mountain. Although the DOE is investigating Yucca Mountain for its capacity to dispose of spent fuel and HLW, not special-case waste, in doing so the DOE is developing the tools necessary to see if Yucca Mountain could be used for disposal of special-case waste, or any other kind of waste. If the DOE is able to demonstrate that disposal of spent fuel and HLW at Yucca Mountain is protective of human health and the environment, it might be able to dispose of some of its special-case waste in the repository in addition to the spent fuel and HLW. Should the DOE be unable to demonstrate 
Table 1. Summary of Disposal Options Examined

\begin{tabular}{||c|c|c||}
\hline $\begin{array}{c}\text { Disposal } \\
\text { Configuration }\end{array}$ & Decision & Reason \\
\hline $\begin{array}{c}\text { Mined consolidated } \\
\text { rock }(>100 \mathrm{ft})\end{array}$ & Eliminated & Duplicating Yucca Mountain efforts \\
\hline $\begin{array}{c}\text { Mined alluvium } \\
(>100 \mathrm{ft})\end{array}$ & Eliminated & Worker safety issues \\
\hline $\begin{array}{c}\text { Deep pits and trenches } \\
(>100 \mathrm{ft})\end{array}$ & Eliminated & Very inefficient; safety hazard \\
\hline $\begin{array}{c}\text { Deep boreholes } \\
(>100 \mathrm{ft})\end{array}$ & Retained & Technically possible; met requirements \\
\hline $\begin{array}{c}\text { Earth-covered tumuli } \\
(<100 \mathrm{ft})\end{array}$ & Eliminated \\
\hline $\begin{array}{c}\text { Concrete structures } \\
(\text { above ground surface })\end{array}$ & Eliminated & Not deep enough \\
\hline $\begin{array}{c}\text { Trenches } \\
(<100 \mathrm{ft})\end{array}$ & Eliminated & Not deep enough \\
\hline $\begin{array}{c}\text { Below-grade concrete } \\
\text { structures }(<100 \mathrm{ft})\end{array}$ & Eliminated & Not deep enough \\
\hline $\begin{array}{c}\text { Shallow boreholes } \\
(<100 \mathrm{ft})\end{array}$ & Eliminated & Not deep enough \\
\hline $\begin{array}{c}\text { Hydrofracture } \\
(<100 \mathrm{ft})\end{array}$ & Eliminated & Injection well concerns; limited application \\
\hline
\end{tabular}

that disposal of spent fuel and HLW at Yucca Mountain is protective of human health and the environment, the DOE could investigate Yucca Mountain for its capacity of dispose of other kinds of waste, including special-case waste. Thus, it seems redundant to consider mined cavities in consolidated rock at the NTS as a GCD-type disposal configuration for special-case waste.

We also considered a disposal system consisting of mined cavities in alluvium. Although personnel experienced in drilling holes in the alluvium at the NTS have informed us that the alluvium tends to be incompetent, ${ }^{\mathrm{a}}$ alluvium has been mined successfully at the NTS [Drellack et al., 1989]. The problem with emplacing waste in a horizontal drift is that once thermal or highspecific activity waste or waste requiring shielding during disposal operations had been emplaced, it might not be possible for a worker to enter the drift to dispose of additional special-case waste because of the heat or radiation. A remote handling system capable of disposing of waste in a horizontal drift would have to be developed to dispose of this additional waste, which violates our guideline of no new equipment or technology. If horizontal drifts offered significant advantages, it might be worth it to develop the remote-handling equipment. However, horizontal drifts appear to

a Memorandum of Record (memo/93/S60) dated October 4, 1993, documenting telephone conversation between Pat Rowe (REECo) and L. Price on April 8, 1993. 
offer significant disadvantages. First, as mentioned above, horizontal drifts are not suitable for disposing of thermal or high-specific activity waste or waste requiring shielding during disposal operations. Second, the surface "footprint" of a 500-ft long, 10-ft diameter horizontal drift would be $5,000 \mathrm{ft}^{2}$, which could be quite significant when it comes to calculating probabilities of human intrusion, a necessary part of the system analyses. Thus, horizontal drifts in alluvium were considered and rejected for the above reasons.

Another subsurface disposal configuration considered as a method of disposing of special-case waste at the NTS is very deep pits and trenches. As stated above, waste needs to be disposed of at least $100 \mathrm{ft}$ below the ground surface. However, a pit or a trench that deep, in the incompetent alluvium of the NTS, would require the wall to have an angle of $45^{\circ} . \mathrm{b}$ Therefore, a pit or trench that was $120 \mathrm{ft}$ deep and $100 \mathrm{ft}$ across at the bottom would be about $340 \mathrm{ft}$ across at the top. Besides posing a safety hazard, such a disposal configuration would require the excavation of 11 $\mathrm{ft}^{3}$ of alluvium for every cubic foot of waste disposed of (not accounting for void space between waste packages), which is very inefficient. We also considered conical excavations that reached depths exceeding $100 \mathrm{ft}$, but such excavations are plagued by the same problems. Therefore, very deep pits and trenches were eliminated from further consideration.

Nuclear event subsidence craters can be considered a special type of deep pit or trench but with the advantage that excavation is not required. Craters would not be appropriate for the disposal of thermal or high-specific activity waste or waste requiring shielding during disposal operations because of the risk to operations personnel. Large objects that do not have any disqualifying characteristics (e.g., require shielding during handling) are about the only kind of special-case waste that is appropriate for disposal in event subsidence craters, and the feasibility of this method of disposal is already being demonstrated in Area 3. Therefore, it does not make sense to consider this type of disposal further; on one hand, the feasibility of using subsidence craters to dispose of bulk LLW is already being demonstrated, so there is no need to perform systems analyses, and, on the other, disposal of other types of special-case waste in subsidence craters is not appropriate.

One obvious disposal configuration was boreholes that are more than $100 \mathrm{ft}$ deep. The existing GCD boreholes at the NTS are only $120 \mathrm{ft}$ deep, which would allow waste to be disposed of only in the bottom $20 \mathrm{ft}$ if we desire to dispose of waste at least $100 \mathrm{ft}$ below the ground surface. However, the capability to drill boreholes much deeper than $120 \mathrm{ft}$ currently exists at the NTS, as will be discussed in Section 2.2.1, so the depth of the borehole does not pose a problem in meeting the $100-\mathrm{ft}$ requirement. Because the technology for deep boreholes exists and is well tested, and because we could not think of any reasons why it should not be considered further, deep boreholes will be one of the disposal configurations retained for further study.

\subsubsection{Near-Surface Disposal}

Near-surface disposal can be broken down into two categories: above-grade disposal and belowgrade disposal. The latter is sometimes referred to as shallow land burial. Examples of each type of disposal are discussed in the following paragraphs. Although these options do not meet the 100-ft depth requirement discussed earlier, they are mentioned below for the sake of completeness.

b Memorandum of Record (memo/93/S60) dated October 4, 1993, documenting telephone conversation between Pat Rowe (REECo) and L. Price on April 8, 1993. 
Two types of above-grade disposal systems are earth-covered tumuli and concrete structures. Disposal in earth-covered tumuli consists of placing the waste in some sort of structure (usually concrete), backfilling around the waste, and covering the entire structure with layers of earthen material such as soil, clay, or rocks. This type of disposal system has been used in France and has been proposed for use at the Idaho National Engineering Laboratory [Trevorrow and Schubert, 1989]. Above-grade concrete structures differ from earth-covered tumuli in that the former do not have the cover of earthen materials. Concrete structures have been proposed, but none have been implemented (as far as we know). The concrete structure would have to provide stability, mechanical strength, a relatively long life-time (perhaps a few hundred years), limited permeability, and intrusion resistance [Trevorrow and Schubert, 1989].

Four types of below-grade disposal are trenches, augered or drilled shafts, below-grade concrete structures, and hydrofracture [Trevorrow and Schubert, 1989]. Trenches are a very common form of LLW disposal, especially in the U.S., as discussed below. Augered shafts have been used for disposal of radioactive waste at the Savannah River Site and at the NTS, as discussed above. Below-grade concrete structures can have a variety of shapes and forms, and these are also a very common form of LLW disposal, particularly in other countries, as discussed below. Disposal by hydrofracture consists of mixing wastes with cement and injecting the resulting grout slurry into rocks by high-pressure injection. The cement solidifies as thin sheets fixed in the host rock. This method of disposal was used at the Oak Ridge National Laboratory for a number of years but has been discontinued because of recent concern by various regulatory agencies about disposal of waste using injection wells [Trevorrow and Schubert, 1989]. Furthermore, this method of disposal can be used to dispose of only those wastes that are in liquid form, a slurry, or that can be made into a slurry. Also, it is not clear that this method of disposal would work well in an unfractured environment such as the alluvium at the NTS. Therefore, hydrofracture is not a candidate GCD configuration and will not be considered further.

Numerous near-surface disposal facilities have been used in other countries for the disposal of LLW, and many more are in the conceptual or planning stage. Canada is planning to use belowgrade concrete vaults situated above the water table in a sand formation to dispose of LLW. The vaults will have permeable floors made of mixtures of sand, clay, and natural zeolite, thus allowing any water that infiltrates into the vault to drain away. Once the vaults are filled, they will be capped with a self-supporting cover of concrete and soil [IAEA, 1992]. Czechoslovakia plans to use trenches with water-proofed concrete walls to dispose of low- and intermediate-level waste. The filled trenches will be covered with concrete caps and impermeable soil upon closure [IAEA, 1992]. France has been disposing of LLW for 20 years using concrete tumuli and monoliths backfilled with concrete. As modules are completed, they are covered with watertight artificial and natural materials to protect the structures against infiltrating rainwater. France has also decided to construct a second facility for the disposal of short-lived low- and medium-level waste. It began operation in early 1992. This second facility also uses above-ground concrete structures to dispose of waste [IAEA, 1992]. Hungary is planning to dispose of LLW using $42 \mathrm{ft}(12.7 \mathrm{~m})$ deep concrete-lined trenches. Layers of waste will be separated by 8 in. $(0.2 \mathrm{~m})$ of concrete. Full cells will be covered with a steel plate followed by layers of concrete, clay, a permeable layer, sand, and cropland [IAEA, 1992]. Japan has developed a conceptual design for disposal of LLW in concrete pits emplaced below the water table. Void space between waste drums will be filled with mortar, and full vaults will be covered with reinforced concrete and $13 \mathrm{ft}(4 \mathrm{~m})$ of soil and earth. Japan plans to maintain institutional control of this facility for 300 years [IAEA, 1992]. Spain has begun construction on a new low- and intermediate-level radioactive waste disposal facility that consists of above-ground concrete vaults. Waste containers, mostly 55 gallon $\left(0.21 \mathrm{~m}^{3}\right)$ drums, will be 
immobilized in concrete disposal containers, forming large concrete blocks that will be stacked inside the concrete vaults. The long-term cover will be composed of layers of sand, clay, gravel, and soil [IAEA, 1992]. Sweden disposes of very LLW by placing the waste packages directly on the ground, filling the voids with sand and gravel, and covering them with a sheet of plastic and at least $3 \mathrm{ft}(1 \mathrm{~m})$ of soil and clay. Grass seed will be sown in the soil. The total activity of waste that may be disposed of in such a manner at a given site is about 3 Curies (100 GBq) [IAEA, 1992]. The U.K. currently disposes of LLW by placing them in trenches that are 20 to $26 \mathrm{ft}$ ( 6 to $8 \mathrm{~m}$ ) deep in clay formations. The wastes are covered by $1.5 \mathrm{~m}$ of cover materials, an impermeable membrane, and a low-permeability layer of clay. The trenches are drained by a pipeline to the sea. This method of disposal is being phased out in favor of disposal in belowground concrete vaults that are founded on clay and drained via a pipeline. Wastes are emplaced in steel containers, void spaces are grouted, and the steel containers are disposed of in the vaults. Vaults will be capped with a multilayer structure and drainage layer, which will include low permeability materials [IAEA, 1992].

In the U.S., LLW has been disposed of in many locations, usually in trenches. The disposal facility at Barnwell, SC has been operating since 1971 . Waste is disposed of in $20 \mathrm{ft}(6 \mathrm{~m})$ deep trenches that have a slightly sloped floor that is covered with a layer of sand. Water percolating through the sand to the lowest point of the trench is collected in a monitored sump. Voids between waste containers are filled with dry soil, and the trench is covered with layers of clay and soil [IAEA, 1992]. The Maxey Flats site in Kentucky disposed of waste from 1963 to 1977 . Wastes were disposed of in trenches that were $20 \mathrm{ft}(6 \mathrm{~m})$ deep and had an impermeable floor. Because of this impermeable layer, water collected in the bottom of the trench. This water had to be pumped out and processed, contributing to the decision to close the site [Lester et al., 1981]. Beatty, NV is the site for a LLW disposal facility that began operation in 1962 but recently discontinued disposal by agreement with the State of Nevada. Wastes are disposed of in trenches that are $50 \mathrm{ft}(15 \mathrm{~m})$ deep. Trenches are capped with soil and other materials to minimize the effects of erosion and runoff [Lester et al., 1981]. The DOE has also disposed of LLW and mixed wastes at the NTS, at the Area 3 and Area 5 Radioactive Waste Management Sites. In Area 5, waste is disposed of in pits and trenches that are constructed in the upper $15-30 \mathrm{ft}$ of alluvium, and the waste is temporarily covered with clay and other fine-grained materials. A final cap is currently being designed [REECo, 1992a]. In Area 3, large, bulky LLW is disposed of in subsidence craters that were created by underground nuclear weapons tests. One crater was originally $50 \mathrm{ft}$ deep and another was $80 \mathrm{ft}$ deep. A closure cap is currently being designed [REECo, 1992b]. Other sites have also been used for disposal of LLW, such as Sheffield, IL; Richland, WA; Hanford, WA; and West Valley, NY. Disposal methods used at these sites are very similar to those already described for other U.S. locations: trenches about $20 \mathrm{ft}$ deep and trench caps made of soil and other materials [Lester et al., 1981].

Earth-covered tumuli, trenches, augered or drilled shafts, and below-grade concrete structures have all been used to dispose of LLW. Some methods have been successful while others have failed. However, there are two problems in using these disposal technologies to dispose of the specialcase wastes that may be destined for disposal at the NTS. The first is that, in these examples, waste is disposed of at depths that are less than $100 \mathrm{ft}$, which violates our requirement that waste be disposed of at least $100 \mathrm{ft}$ below the ground surface. It is important to note that these nearsurface disposal configurations may be perfectly adequate for the wastes that are disposed of in them. However, because the inventory of waste that may be destined for disposal at the NTS is not well defined, and because much of it could be, by law, unsuitable for near-surface disposal, we require that the disposal configurations considered be capable of disposing of waste at depths 
greater than $100 \mathrm{ft}$. The second problem is that, to date, performance assessment analyses and information obtained from site characterization activities at the NTS have indicated that surficial processes (e.g., erosion, plant intrusion, animal intrusion) are the ones most likely to result in releases from the disposal facility. That is, the processes that transport wastes at depth do so much more slowly than those that are active at the surface. Therefore, it would seem that the better disposal designs are those that can place waste at depths where surficial processes have less of an effect. Earth-covered tumuli, trenches, below-grade concrete structures, and shallow augered or drilled shafts tend to be affected by surficial processes more than disposal methods that emplace wastes at greater depths. Therefore, because near-surface disposal configurations are not capable of disposing of wastes at sufficient depth, they will not be considered further.

\subsection{Boreholes and their Options}

After examining the subsurface and near-surface disposal configurations discussed above, deep boreholes were the only disposal configurations that remained. Various options can be exercised in conjunction with boreholes, and these are discussed in the following sections.

\subsubsection{Borehole Depth}

The currently existing 120-ft deep GCD boreholes were excavated with an auger rig. In general, auger rigs can excavate to a depth of no more than $150 \mathrm{ft}$ and do not require the use of drilling fluid. Since waste must be disposed of at least $100 \mathrm{ft}$ below the ground surface, a 150 - $\mathrm{ft}$ deep borehole would permit a waste column $50 \mathrm{ft}$ high. With this configuration, $3 \mathrm{ft}^{3}$ of alluvium would have to be excavated for every cubic foot of waste disposed of.

Instead of using an auger, large-diameter boreholes (see Section 2.2.2) could be drilled with modified drilling rigs and water-based drilling fluid. Such rigs can drill boreholes $2,000 \mathrm{ft}$ deep, ${ }^{\mathrm{c}}$ far deeper than needed if we desire to keep wastes above the alluvial water table, which is presently about $800 \mathrm{ft}$ below the ground surface in Frenchman Flat. The rigs capable of drilling to these depths are currently in use at the NTS, so borehole depth is not limited by available equipment or technology. The use of water-based drilling fluid is somewhat of a concern because it is desirable to keep the borehole as dry as possible. However, given the exceedingly arid climate, the dryness of the surrounding alluvium, the 10,000-year time scale of interest (for 40 CFR 191 [EPA, 1985]), the fact that there could be a delay of several years between when a borehole is created and when waste is emplaced in it and that air can be circulated through the boreholes as they near completion in order to dry them out, ${ }^{d}$ the use of water-based drilling fluid should not be a problem. The effects of using a water-based fluid on the performance of the disposal system will be accounted for in the system analyses. The volume of alluvium excavated for every cubic foot of waste disposed of depends on how deep the borehole is, but for a 600-ft deep borehole with a 500-ft high waste column, $1.2 \mathrm{ft}^{3}$ of alluvium would have to be excavated for every cubic foot of waste disposed of.

The depth of boreholes used for the future disposal of special-case waste, then, is not limited by available technology or equipment, but instead is driven by post-closure safety concerns. Having a few deep boreholes rather than many shallow boreholes minimizes the probability of human

c Memorandum of Record (memo/93/S60) dated October 4, 1993, documenting telephone conversation between David Thomson (SNL) and L. Price on April 6, 1993.

d Memorandum of Record (memo/93/S60) dated October 4, 1993, documenting telephone conversation between Pat Rowe (REECo) and L. Price on April 8, 1993. 
intrusion by minimizing the total surface area of all the boreholes. Also, deeper boreholes are more efficient than shallower boreholes in terms of volume of alluvium excavated per volume of waste emplaced and emplace waste farther from the ground surface. On the other hand, we probably do not want the boreholes to be as deep as the water table because of post-closure safety concerns. Just how far above the water table the waste should be is driven by the rate of downward radionuclide transport, given present recharge rates and likely future recharge rates. Likewise, while all disposal configurations considered will allow waste to be disposed of at least $100 \mathrm{ft}$ below the ground surface, the rate of radionuclide transport upward in both gas and liquid phases may indicate that waste should be disposed of even deeper than $100 \mathrm{ft}$. These post-closure safety concerns will determine the maximum depth of the boreholes and the maximum height of the waste column, given the associated uncertainties in modeling the waste and disposal system.

\subsubsection{Borehole Diameter}

Eleven of the thirteen existing GCD boreholes are $10 \mathrm{ft}$ in diameter; the other two are $12 \mathrm{ft}$ in diameter. These two diameters represent typical borehole diameters for augers, although they can have diameters as great as $16 \mathrm{ft} .{ }^{\text {e }}$ Modified drilling rigs currently at the NTS can drill boreholes with 8-, 9-, 10-, or 12-ft diameters. There is a possibility that the DOE may obtain a drilling rig from Australia that is capable of excavating boreholes $20 \mathrm{ft}$ in diameter. ${ }^{\mathrm{f}}$ Large diameter boreholes are preferable because they are more likely to be able to dispose of large, bulky, or odd-shaped waste than a smaller diameter borehole and because, in general, the disposal cost per $\mathrm{m}^{3}$ decreases as the diameter of the borehole increases [Dickman et al., 1984]. One of the concerns with largediameter boreholes is that they are somewhat more susceptible to subsidence, especially after waste packages have disintegrated. However, the amount of subsidence can be kept to a minimum by eliminating voids in emplacing the waste, packing the backfill material carefully, and monitoring for subsidence during the period of institutional control (100 years after closure). We could find no other concerns that countered the tendency toward larger diameter boreholes, so in keeping with the concept of using available technology and equipment, we will assume that all boreholes are $12 \mathrm{ft}$ in diameter.

\subsubsection{Borehole Location}

There are two alluvium-filled closed basins at the NTS: Frenchman Flat and Yucca Flat. Assuming that both are equally available for the development of a GCD facility, some of the factors that influence the selection of a site are the potential for erosion and the depth to the water table. The potential for erosion varies from location to location, so it would make sense to situate a GCD facility at a site that had a relatively low potential for erosion. In general, the potential for erosion is lower toward the center of a basin than it is higher up on the alluvial fan. Thus, concerns about erosion will, in general, tend to favor sites closer to the center of a given basin, although the center of the basin should be avoided. The lowest point in the basin tends to be a playa (dry lake bed) which contains a few inches of water several times per year, so the playas would not be a good location for the boreholes. Also, not much is known about recharge at the center of these basins. This is in contrast to the desire to locate a facility such that the depth of the water table is maximized, allowing the depth of the borehole and the amount of waste in a particular borehole to be maximized, given that changes in climate may play a role in determining how far the waste

e Memorandum of record (memo/93/S60) dated October 4, 1993, documenting telephone conversation between Mike Butler (LLNL) and L. Price on April 7, 1993.

f Memorandum of Record (memo/93/S60) dated October 4, 1993, documenting telephone conversation between Pat Rowe (REECo) and L. Price on April 8, 1993. 
should be from the water table. The water table is relatively horizontal (at least in Frenchman Flat), so the depth of the water table increases as the ground surface elevation increases. Thus, the desire to minimize the erosion potential and to maximize the distance from the ground surface to the water table are often in competition and are the main forces in determining the best location for a future GCD facility.

\subsubsection{Borehole Spacing}

Because each borehole can be drilled relatively independently of other boreholes, the spacing of boreholes becomes a variable in examining potential borehole configurations. The primary concern in spacing boreholes is that they be far enough apart to allow the movement of large and heavy equipment but not so far apart that the facility becomes unnecessarily large and that ensuring the safety and security of the entire facility becomes unreasonably expensive. The spacing of boreholes is not a factor in calculating the probability of human intrusion, given present models for such calculations. It is the total surface area of the boreholes that is used in calculating the probability of human intrusion, not the distance between boreholes.

The only other concern in determining how far apart the boreholes should be is with respect to the disposal of thermal wastes such as sealed sources or spent fuel. As experience with the GCD Test borehole has shown, it is desirable to keep volatile wastes (such as tritium or radon) away from thermal sources because the increased temperature greatly enhances the transport of volatile wastes in the gas phase. Therefore, boreholes containing volatile wastes will need to be far enough from boreholes containing thermal wastes to keep the increase in temperature in the former to a minimum. On the other hand, increased temperatures will likely cause moisture to diffuse outward from the heat source, drying out the alluvium and eliminating liquid phase transport of radionuclides as a transport mechanism until temperatures drop significantly. In this respect, increased temperatures result in the increased isolation of waste from humans and the accessible environment. While we know of no regulations that limit the increase in temperature resulting from disposing of thermal waste, it is probably a good practice to dispose of thermal wastes such that the temperature at the ground surface and a few meters below is not affected. In so doing, the habitat of endangered species (such as the desert tortoise) and other wildlife will not be destroyed. Furthermore, it is probably good practice to dispose of thermal waste such that temperatures in the borehole do not adversely affect the waste packages or other engineered barriers.

Thus, boreholes can be as close together as operational concerns will allow, except when thermal wastes are concerned. The distance between boreholes containing thermal wastes and those containing volatile wastes is driven by the resulting changes in temperature, which can be estimated by thermal analyses. Thermal analyses will be performed when the system analyses are performed, if necessary.

\subsubsection{Physical Barriers}

The physical barriers to radionuclide transport in and around the existing GCD boreholes consist of the packages that the wastes are in (e.g., 55 gallon drums, boxes), the undisturbed alluvium, and the alluvium with which the boreholes were backfilled. Three of the boreholes contain probertite to prevent nuclear criticality. Even with such meager physical barriers, the GCD boreholes appear to be capable of isolating the wastes emplaced in them from the accessible environment [Baer et al., 1993; Price et al., 1993]. It is not a foregone conclusion, however, that the same meager physical barriers will be as effective in isolating other wastes. Therefore, one of 
the options in continuing to use boreholes for GCD is to include physical barriers to liquid phase radionuclide transport, such as layers of clay and gravel, and physical barriers to gas phase radionuclide transport, such as clay. As used in this report, clay is defined as hydrous aluminum silicates and other minerals with particle sizes on the order of 2-4 $\mu \mathrm{m}$ [Drever, 1982]. Gravel consists of material with particle sizes that are on the order of 2-4 mm [Tarbuck and Lutgens, 1984]. Each type of material has its advantages, as discussed in the following paragraph.

In general, because clay is a very fine-grained material and gravel is coarse, pore sizes in clay are much smaller than those in gravel. This difference in pore size makes clay a better barrier to liquid phase flow and diffusion under saturated conditions and makes gravel a better barrier under unsaturated conditions. Under saturated (or very wet) conditions, water will flow much more easily through gravel than through clay because the intermolecular forces between the water and the clay molecules impede the flow of water, while such forces are not as significant in the largerpore gravel [Tarbuck and Lutgens, 1984], and the diffusion of radionuclides is likely to be faster in gravel because the larger pores result in a less tortuous path for the radionuclides (i.e., lower tortuosity). At low moisture contents, the reverse is probably true because at a given matric potential, clays tend to have higher moisture contents than gravel or other materials with large particle sizes [Ward, 1967]. Therefore, water may flow more easily through clay than gravel and radionuclides may diffuse more rapidly in clay than in gravel [Fetter, 1980], assuming that the inverse relationship between moisture content and tortuosity holds true. The moisture content (or saturation) at which one becomes a better barrier than the other is dependent on the properties of the specific gravel and clay, and so a number cannot be given here. Clay could also be considered a chemical barrier because its high ratio of surface area to volume provides many sorption sites for radionuclides.

Other materials that can be used as physical barriers to liquid phase radionuclide transport include concrete, grout, steel plates, and sand (see Section 2.1.2). Concrete and grout tend to crack with age, so their long-term effectiveness as physical barriers is questionable. However, concrete and grout will be considered as chemical barriers (see Section 2.2.6). Metal plates probably would not be useful as a physical barrier to radionuclide transport in an arid environment such as the NTS and at depth, but will be used as physical barriers to human intrusion. For example, a metal disk with the same diameter as the borehole or a metal cone-shaped object that would deflect the drill bit could be used as a physical barrier to human intrusion. Sand is used because of its permeability (under saturated conditions), but gravel will serve the same function just as well (if not better) because it has slightly larger particles than sand. However, sand could also be used as a physical barrier in the boreholes if, for some reason, gravel was not available.

Volatile radionuclides (i.e., those that are transported in the gas phase) are much more difficult to isolate from humans and the environment. The four volatile radionuclides that have been identified as potentially being components of special-case waste are ${ }^{3} \mathrm{H},{ }^{14} \mathrm{C},{ }^{129} \mathrm{I}$, and ${ }^{222} \mathrm{Rn}$ [Price and Durán, 1994]. Experience has shown that ${ }^{3} \mathrm{H}$ and ${ }^{222} \mathrm{Rn}$ (half-lives of 12.3 years and 3.8 days, respectively) can be isolated from the environment effectively simply by increasing the depth at which these radionuclides are disposed of [Dickman, 1989; Price et al., 1993]. However, ${ }^{14} \mathrm{C}$ and ${ }^{129}$ I may be more difficult to isolate because they have much longer half-lives $\left(5,700\right.$ years for ${ }^{14} \mathrm{C}$ and $1.6 \times 10^{7}$ years for $\left.{ }^{129} \mathrm{I}\right)$. The only type of material that we could think of that might be an effective physical barrier to gas phase radionuclide transport was clay because its small pore size and increased tortuosity serve to limit gas phase diffusion. Diffusion will be the only significant gas phase transport process because the depth at which the wastes are disposed of eliminates evapotranspiration and barometric pumping as significant transport processes. 
We will not consider physical barriers that might be provided by an elaborate waste form or sophisticated waste packaging. Such barriers are not being considered because many of the wastes that are potential candidates for GCD are not suitable for disposal elsewhere because of their waste form or waste packaging. In other words, many of the waste forms or waste packages that cause a particular waste to become special-case waste must be acceptable for disposal at the proposed GCD facility. Otherwise, the GCD facility will not be fulfilling its intended purpose of disposing of wastes that cannot be disposed of elsewhere. This is not to say that no packaging will be required. For the system analyses, it will be assumed that the waste is in 55-gallon metal drums but that the drums are breached upon emplacement, making the waste available for transport immediately. The eventual disintegration of the drums will be assumed to have no effect on either chemical or physical engineered barriers. Some minimal packaging and waste form requirements will most likely be developed at a later time.

Finally, the undisturbed alluvium also acts as a physical barrier to radionuclide transport from the GCD boreholes, but it will not be thought of as an engineered physical barrier for the purposes of the system analyses. However, in modeling the transport of radionuclides through the undisturbed alluvium, the properties of the alluvium that make it a physical barrier will be accounted for. As in previous performance assessments, the undisturbed alluvium will be assumed to be homogeneous.

\subsubsection{Chemical Barriers}

In addition to physical barriers, various materials could be used as backfill to alter the chemical environment of the boreholes to inhibit the dissolution and transport of radionuclides. An example of such a material is probertite, which appears to have a buffering effect on both $\mathrm{pH}$ and $\mathrm{CO}_{2}$ pressure $\left(\mathrm{pCO}_{2}\right)$ [Stockman, 1992]. Another candidate is cement-based barriers (e.g., grouts, concrete) that have the potential to immobilize ${ }^{14} \mathrm{C}$ by precipitating calcium-carbonate-bearing solids [Dayal and Reardon, 1992]. Zeolites and clays can also act as chemical barriers because of their tendency to retard some radionuclides by means of ion-exchange reactions. Of course, the selection of a chemical barrier is dependent on the radionuclides disposed of and the type of package they are in. Therefore, it is difficult to know a priori exactly what material to use as a chemical barrier. It is not the purpose of the system configuration study to design a GCD facility for special-case waste; therefore, no research has been or will be done under this task to find the optimal chemical barrier for each waste type.

As above, the undisturbed alluvium will not be considered to be an engineered chemical barrier. However, the sorption properties of the alluvium will be accounted for in modeling the transport of radionuclides through the alluvium. 


\subsection{DISPOSAL CONFIGURATIONS TO BE CONSIDERED IN THE SYSTEM ANALYSES}

Given the variety of options that can be exercised with boreholes, it is necessary to limit the configurations to be considered in the system analyses to a manageable number. To accomplish this, we will not allow borehole diameter, borehole location, and borehole spacing to vary. Borehole diameter has already been fixed at $12 \mathrm{ft}$ (see Section 2.2.2). Borehole location and borehole spacing will also have fixed values, as discussed in the following paragraphs.

Because it is beyond the scope of this task to actually site a GCD facility, we will assume that the boreholes are located such that the unsaturated zone, assuming the maximum expected erosion has occurred, is $650 \mathrm{ft}(200 \mathrm{~m})$ deep. The maximum expected erosion is being calculated as a part of the performance assessment for the GCD boreholes at the NTS. The reasoning behind this assumption is as follows. The water table below Frenchman Flat is at an elevation of about 2400 $\mathrm{ft}$ above mean sea level (MSL), while the elevation of the ground surface at the lowest point in Frenchman Flat is about $3050 \mathrm{ft}$ above MSL. Barring a radical transformation in the topography of Frenchman Flat, it is not physically possible for erosion to cause the elevation of the lowest point in Frenchman Flat to drop below the current value of $3050 \mathrm{ft}$. Therefore, assuming that the water table does not rise, the minimum distance between the ground surface and the water table is $(3050-2400)=650 \mathrm{ft}$. While this assumption is based on elevations in Frenchman Flat, it is also reasonable for Yucca Flat because the thickness of the unsaturated zone in Yucca Flat is greater than it is in Frenchman Flat [Bedinger et al., 1984]. Making this assumption eliminates the need to consider borehole location (i.e., Frenchman or Yucca Flat) in defining disposal configurations.

Likewise, the issue of borehole spacing is also a design issue, something to be addressed when the wastes to be disposed of are more clearly defined. For thermal wastes, Dickman [1989] suggests a "rule of thumb" that boreholes should be separated by a minimum of 1 meter for every 100 watts thermal to keep temperatures between 30 and $40^{\circ} \mathrm{C}$. For example, two boreholes, each containing 3,500 watts of thermal wastes, should be separated by a minimum of $35 \mathrm{~m}$. We will assume that boreholes are spaced far enough apart so that the boreholes can be modeled as being independent of each other.

Setting the borehole diameter to $12 \mathrm{ft}$, assuming that the distance from the ground surface to the water table is $650 \mathrm{ft}$, and assuming that boreholes are spaced far enough apart so that they are independent of each other, reduce the number of factors to be considered in defining disposal configurations. The only factors remaining are depth, chemical barriers, and physical barriers. Therefore, we will define four baseline configurations. The first one will have no engineered physical or chemical barriers, the second will have chemical barriers, the third will have physical barriers, and the fourth will have both physical and chemical barriers. All will vary in depth, as discussed below.

Defining disposal configurations is being approached in this manner because we believe it will be helpful for the DOE to have some idea not only of the kind of waste that can be disposed of but also of the effort it will take to ensure that the waste remains isolated from humans and the accessible environment for long periods of time. Some wastes are more difficult to dispose of safely than others because of their propensity to migrate and, hence, may require the use of additional engineered barriers as compared to less mobile waste. 


\subsection{Level One}

The Level One configuration does not include any engineered chemical or physical barriers. In this configuration, the boreholes are backfilled with sifted native alluvium, just as most of the current GCD boreholes are. The height of the waste column will be allowed to vary from $150 \mathrm{ft}$ to $450 \mathrm{ft}$. That is, the distance from the ground surface to the top of the waste (assuming the maximum expected erosion has occurred) will vary from $250 \mathrm{ft}$ to $100 \mathrm{ft}$, and the distance from the water table to the bottom of the waste will also vary from $250 \mathrm{ft}$ to $100 \mathrm{ft}$. The reason for the $100-\mathrm{ft}$ minimum distance between the ground surface and the top of the waste has already been discussed. It is assumed that the maximum expected erosion has occurred so that erosion does not have to be considered as a scenario in the system analyses. The $250-\mathrm{ft}$ maximum distance between the ground surface and the top of the waste is intended to provide additional isolation of the waste from the ground surface, should $100 \mathrm{ft}$ not be sufficient. The $100-\mathrm{ft}$ minimum distance between the bottom of the waste and the water table is based on a desire to keep contaminated ground water from reaching the water in 10,000 years [EPA, 1985]. REECo [1993] estimated a water travel velocity through the vadose zone of $1 \times 10^{-2} \mathrm{ft} / \mathrm{yr}\left(3 \times 10^{-3} \mathrm{~m} / \mathrm{yr}\right)$ by measuring water contents in the vadose zone and estimating unsaturated hydraulic conductivities. Based on this estimate, contaminated ground water will not reach the water table in 10,000 years if the bottom of the waste is $100 \mathrm{ft}$ above the water table. The 250 - $\mathrm{ft}$ maximum distance between the bottom of the waste and the water table addresses the possible increase in recharge resulting from a change in climate. All of the above distances are guidelines and are subject to change should the system analyses indicate a change is necessary.

Based on these dimensions, the volume of an individual borehole varies from $16,964 \mathrm{ft}^{3}$ to 50,893 $\mathrm{ft}^{3}\left(480 \mathrm{~m}^{3}\right.$ to $\left.1,441 \mathrm{~m}^{3}\right)$. Assuming a $50 \%$ efficiency (i.e., waste packages take up half the available space in the borehole and backfill occupies the other half), each borehole will hold from $8,482 \mathrm{ft}^{3}$ to $25,447 \mathrm{ft}^{3}\left(240 \mathrm{~m}^{3}\right.$ to $\left.721 \mathrm{~m}^{3}\right)$ of waste. This configuration relies on the natural conditions at the site to provide isolation of the waste from humans and the accessible environment. Clearly, it is the least complicated of the four configurations, may provide the least isolation, and is the least costly.

In conducting the system analyses, we will examine the performance of the Level One configuration for each type of waste, beginning with the highest volume of waste and making it smaller as necessary (i.e., allowing more alluvium between the waste and the ground surface or the waste and the water table as necessary). If the analyses indicate that a particular type of waste can safely be disposed of using the Level One configuration, then system analyses will not be repeated for that waste type using other disposal configurations. If, on the other hand, the analyses indicate that a particular waste cannot be disposed of safely in the Level One configuration, the system analyses will be repeated for that waste assuming it is disposed of in the Level Two and Level Three configurations.

\subsection{Level Two}

The second disposal configuration includes chemical barriers to radionuclide dissolution and transport. As mentioned above, examples of such barriers are probertite, clays, zeolites, cementbased grouts, and concrete. In this configuration, the material that acts as a chemical barrier is used to backfill the borehole as the waste is being emplaced, just as the probertite was used in the current GCD boreholes 1,2, and 3 [Chu and Bernard, 1991]. A relatively thin layer (about $5 \mathrm{ft}$ thick) of the material could be placed above and below the waste in the borehole, but most of the 
material is in the part of the borehole where the waste is emplaced and some (perhaps about a foot thick) is between the waste and the borehole wall. Thus, the contact between the chemical barrier and the waste is maximized.

As in the Level One configuration, the waste column varies from $150 \mathrm{ft}$ to $450 \mathrm{ft}$ high, with an assumed packing efficiency of $50 \%$. If analyses indicate that a particular waste type can safely be disposed of using the Level Two configuration, then system analyses will be repeated for that waste type using the Level Three configuration but not the Level Four configuration. Conversely, if analyses indicate that a particular waste cannot be disposed of safely in the Level Two configuration, the system analyses will be repeated for that waste assuming it is disposed of in the Level Three configuration. The reason for such an approach is that a waste might be safely disposed of using either the Level Two or Level Three configuration, but Level Three might be more cost-effective and therefore the more desirable disposal configuration. It is assumed that a Level Four configuration is more expensive than either Level Two or Level Three.

\subsection{Level Three}

The third disposal configuration includes physical barriers to ground water flow and radionuclide diffusion, primarily gravel and clay. Which is the more effective barrier to radionuclide transport depends on how wet (or dry) the gravel and clay are. Under the dry conditions currently at the NTS, gravel would probably be the more effective barrier because of its lower hydraulic conductivity and, perhaps more importantly, higher tortuosity and lower moisture content (i.e., lower effective diffusion coefficient) under such conditions [Fetter, 1980]. Because recharge is thought to be so low as to be negligible [Conrad, 1993], it is currently thought that diffusion of radionuclides in the liquid phase is the primary radionuclide transport process. However, the possibility of a change in climate cannot be neglected and is the subject of study for the performance assessment for the existing GCD boreholes. Should a change in climate result in wetter conditions and significant recharge, clay might become the more effective barrier and advection might replace diffusion as the primary radionuclide transport process.

Because the NTS is presently an arid site and because it may remain that way for the next 10,000 years, the Level Three configuration will consist of placing a relatively thin layer (about $5 \mathrm{ft}$ ) of gravel above and below the waste and backfilling with gravel as the waste is being emplaced. The waste would be emplaced such that space (approximately $1 \mathrm{ft}$ ) is left between the waste and the wall of the borehole, and this space is filled with gravel. Thus, the gravel, like the chemical barrier of the Level Two configuration, will completely surround the waste. A layer of clay, also a few feet thick, will be placed above the gravel on top of the waste. This layer of clay will act as a low permeability barrier to downward ground water flow (should recharge increase) and cause water to flow primarily downward through the alluvium surrounding the borehole, not through the borehole itself. While it is tempting to add additional gravel and clay layers above the borehole, it is not clear that such layers improve the isolation capability of the boreholes because of their limited lateral extent. Contaminated ground water or dissolved radionuclides would likely move sideways above or below the impermeable layer towards undisturbed alluvium, thus circumventing the engineered barriers. Therefore, additional layers will not be added.

As in the Level One and Level Two configurations, the waste column will vary from $150 \mathrm{ft}$ to 450 $\mathrm{ft}$ high and packing efficiency will be $50 \%$. Also, analysis of a particular waste type in the Level Four configuration will be considered only if that waste type cannot be disposed of safely in either the Level Two or the Level Three configuration. 


\subsection{Level Four}

The Level four configuration includes both chemical and physical barriers to radionuclide transport and is the most complicated and expensive configuration. The best way to combine these barriers depends on the chemical barrier used. For example, a concrete sleeve $12 \mathrm{ft}$ in diameter and a few inches thick could be used to line the borehole, and the waste could be emplaced inside this sleeve and backfilled with gravel. Or, the waste could be encased in concrete before being emplaced in the boreholes and gravel could be used to backfill around the concrete monoliths. Some care must be taken in combining these two types of barriers because the physical characteristics of the chemical barriers (e.g., clay) could render the physical barrier useless and vice versa. It is assumed, for the purposes of this study, that physical and chemical barriers can be combined in such a way that both remain effective.

As in the other three configurations, the waste column will vary from $450 \mathrm{ft}$ to $150 \mathrm{ft}$ high and packing efficiency will be $50 \%$. If analyses indicate that a particular waste cannot be disposed of safely in the Level Four configuration, we will then conclude that such a waste is not a suitable candidate for GCD at the NTS. 


\subsection{SUMMARY}

The DOE is responsible for disposing of a variety of radioactive waste, some of which is considered special-case waste because it does not currently have a clear disposal option. The objective of this report is to present options for the disposal of this special-case waste at the NTS. The disposal options will be used in performing system configuration analyses to determine which wastes are suitable candidates for disposal at the NTS. The disposal configurations are not highly detailed because it is not the purpose of this report to design GCD-type disposal systems, the waste inventory information needed to design such systems is not available, and detailed configurations are not needed for the system analyses.

Four different options for subsurface disposal of special-case waste were proposed: disposal in mined consolidated rock, in mined alluvium, in deep pits or trenches, and in deep boreholes. Six different options for near-surface disposal of special-case waste were presented: earth-covered tumuli, above-grade concrete structures, trenches, below-grade concrete structures, shallow boreholes, and hydrofracture. Disposal in mined consolidated rock was eliminated because considering it would be duplicating efforts already underway regarding Yucca Mountain. Disposal in mined alluvium was eliminated because the alluvium is too incompetent for such a disposal method. Disposal in deep pits or trenches was eliminated because they are very inefficient; the walls of such pits or trenches would lie at an angle of about $45^{\circ}$, requiring the excavation of about $11 \mathrm{ft}^{3}$ of alluvium for every cubic foot of waste disposed of. The near-surface disposal methods (except for hydrofracture) were eliminated because they do not meet the requirement of disposing of wastes at least $100 \mathrm{ft}$ below the ground surface. Hydrofracture was eliminated because of concerns about such a method being considered an injection well and because it has a limited application. The only disposal configuration retained was deep boreholes.

Therefore, the four proposed disposal configurations consist of boreholes with engineered barriers ranging from only the native alluvium to a combination of gravel and concrete, for example. The Level One configuration has only sifted native alluvium as a barrier to radionuclide transport, the Level Two configuration has chemical barriers, Level Three has physical barriers, and Level Four has both chemical and physical barriers. If analyses indicate that a particular waste cannot be disposed of safely using any one of these four disposal configurations, then we will conclude that such a waste is not suitable for disposal using boreholes at the NTS and will need to be disposed of elsewhere. 


\subsection{REFERENCES}

Apted, M. J., K. Andersson, and C. Pescatore, 1993. "Review of International Near-Field Modelling for High-Level Waste Disposal," in Proceedings of the Fourth Annual International High-Level Radioactive Waste Management Conference, Las Vegas, NV, April 26-30, 1993, pp. 451-455, American Nuclear Society, La Grange Park, IL, and American Society of Civil Engineers, New York, NY.

Baer, T. A., N. E. Olague, L. L. Price, and S. H. Conrad, 1993. "Results from the Second Performance Assessment Iteration for the Greater Confinement Disposal Facility," in Proceedings of the Fourth Annual International High-Level Radioactive Waste Management Conference, Las Vegas, NV, April 26-30, 1993, pp. 252-260, American Nuclear Society, La Grange Park, IL, and American Society of Civil Engineers, New York, NY.

Bedinger, M. S., J. R. Harrill, W. H. Langer, J. M. Thomas, and D. A. Mulvihill, 1984. Maps Showing Ground-Water Levels, Springs, and Depth to Ground Water, Basin and Range Province, Nevada, Water-Resources Investigations Report 83-4119-B, U.S. Geological Survey, Denver, CO.

Chu, M. S. Y. and E. A. Bernard, 1991. Waste Inventory and Preliminary Source Term Model for the Greater Confinement Disposal Site at the Nevada Test Site, SAND91-0170, Sandia National Laboratories, Albuquerque, NM.

Conrad, S. H., 1993. "Using Environmental Tracers to Estimate Recharge Through an Arid Basin," in Proceedings of the Fourth Annual International High-Level Radioactive Waste Management Conference, Las Vegas, NV, April 26-30, 1993, Vol. 1, pp. 132-137, American Nuclear Society, La Grange Park, IL, and American Society of Civil Engineers, New York, NY.

Dayal, R. and E. J. Reardon, 1992. "Cement-Based Engineered Barriers for Carbon-14 Isolation," Waste Management, Vol. 12, pp. 189-200.

Dickman, P. T., 1989. Greater Confinement Disposal Test at the Nevada Test Site: Final Technology Report, Reynolds Electrical \& Engineering Co., Inc., Las Vegas, NV.

Dickman, P. T., A. T. Vollmer, and P. H. Hunter, 1984. Operational Technology for Greater Confinement Disposal, DOE/NV/10327-14, Reynolds Electrical \& Engineering Co., Inc., Las Vegas, NV.

DOE, 1988. "Radioactive Waste Management," DOE Order 5820.2A, September 26, 1988.

DOE, 1992. Characteristics of Potential Repository Wastes, DOE/RW-0184-R1, Volume 2, Oak Ridge National Laboratory, Oak Ridge, TN.

Drellack, S. L., P. H. Thompson, and C. J. Rayburn, 1989. Geology of the U-1A.01 Horizontal Drift Complex, Southwestern Yucca Flat, Nevada Test Site, DOE/NV/10322-37, Fenix and Scisson, Inc., Mercury, NV 89023 
Drever, J. I., 1982. The Geochemistry of Natural Waters, Prentice-Hall, Englewood Cliffs, NJ.

EPA, 1985. "40 CFR Part 191: Environmental Standards for the Management and Disposal of Spent Nuclear Fuel, High-Level, and Transuranic Radioactive Wastes; Final Rule," Federal Register, pp. 38066-38089, Thursday, September 19, 1985.

EPA, 1993. "40 CFR Part 191: Environmental Standards for the Management and Disposal of Spent Nuclear Fuel, High-Level, and Transuranic Radioactive Wastes; Proposed Rule," April 26, 1993.

Fetter, C. W., 1980. Applied Hydrogeology, Charles E. Merrill Publishing Co., Columbus, OH.

IAEA, 1992. Review of Available Options for Low Level Radioactive Waste Disposal, IAEATECDOC-661, International Atomic Energy Agency, Vienna, Austria.

Lester, D., D. Buckley, S. Donelson, V. Dura, M. Hecht, W. Horton, T. Nakai, T. Pasternak, L. Robertson, R. Stula, and J. Stoddard, 1981. System Analysis of Shallow Land Burial, NUREG/CR-1963, Vol. 2, Nuclear Regulatory Commission, Washington, DC.

NAC, Chapter 445. Nevada Administrative Code, 445.422 to 445.4278 , Underground Injection Control.

NEAA, 1980. Department of Energy National Security and Military Applications of Nuclear Energy Authorization Act, Public Law 96-164.

NEPA, 1978. National Environmental Policy Act, 42 U.S.C. 43221 et seq.

NRC, 1993. "Licensing Requirements for Land Disposal of Radioactive Waste," Code of Federal Regulations. Title 10. Part 61, U.S. Government Printing Office, Washington, DC.

NWPA, 1982. Nuclear Waste Policy Act, Public Law 97-425, 42 U.S.C. § 10101 et seq.

Price, L. L., S. H. Conrad, D. A. Zimmerman, N. E. Olague, K. C. Gaither, W. B. Cox, J. T. McCord, and C. P. Harlan, 1993. Preliminary Performance Assessment of the Greater Confinement Disposal Facility at the Nevada Test Site, Volume 2: Technical Discussion, SAND91-0047, Sandia National Laboratories, Albuquerque, NM.

Price, L. L. and F.A. Durán, 1994. "Characteristics of Special-Case Wastes Potentially Destined for Greater Confinement Disposal at the Nevada Test Site," SAND94-2106, Sandia National Laboratories, Albuquerque, NM.

REECo, 1992a. Draft Closure Plan for the Area 5 Radioactive Waste Management Site, Reynolds Electrical \& Engineering Co., Inc., Las Vegas, NV.

REECo, 1992b. Draft Closure Plan for the Area U3AH/AT Land Disposal Unit, Reynolds Electrical \& Engineering Co., Inc., Las Vegas, NV. 
REECo, 1993. Site Characterization and Monitoring Data from Area 5 Pilot Wells, Nevada Test Site, Nye County, Nevada, Special Projects Section, Reynolds Electrical and Engineering Co., Inc., Las Vegas, NV.

Stockman, H. W., 1992. "Refinement of Plutonium Solubility Estimates for The Greater Confinement Disposal Project, Area 5, Nevada Test Site," interim report to DOE Nevada Field Office from Sandia National Laboratories, August 13, 1992.

Tarbuck, E. J., and F. K. Lutgens, 1984. The Earth: An Introduction to Physical Geology, Charles E. Merrill Publishing Company, Columbus, $\mathrm{OH}$.

Trevorrow, L. E. and J. P. Schubert, 1989. "Greater-Confinement Disposal," in Near-Surface Land Disposal, pp. 169-235, J. H. Kittel, ed., Harwood Academic Publishers, New York, NY.

UMTRCA, 1978. Uranium Mill Tailings Radiation Control Act of 1978, Public Law 95-604.

Ward, R. C., 1967. Principles of Hydrology, McGraw-Hill Publishing Company Limited, New York, NY. 


\section{DISTRIBUTION}

\section{Federal Agencies}

U.S. Department of Energy

Office of Environmental Management

Attn: T. P. Grumbly, EM-1

Forrestal Building

Washington, DC 20585-0002

U.S. Department of Energy

Office of Waste Management [11]

Attn: David Huizenga, EM-30

Jill E. Lytle EM-30

Jay Rhoderick, EM-321

Joe Coleman, EM-32

Betty Shackleford, EM-331

Wayne Nobles, EM-332

Mark Frie, EM-34

Warren Black, EM-351

Lynne Wade, EM-351

Leanne Smith, EM-60

Joseph Boda, EM-363

Washington, DC 20585-0002

U.S. Department of Energy

Nevada Operations Office [6]

Attn: Doug Duncan

Joe Fiore

Joe Ginanni [2]

Carl Gertz

Technical Information Office

2743 S. Highland Drive

Las Vegas, NV 89193-8518

U.S. Department of Energy

WIPP Project Integration Office

Attn: Paul Dickman

One Park Square, Suite 903

6501 Americas Parkway NE

Albuquerque, NM 87110

U.S. Department of Energy

WIPP Task Force

Attn: B. Bower

12800 Middlebrook Road, Suite 400

Germantown, MD 20874
U.S. Department of Energy

Carlsbad Area Office

Attn: George Dials, Manager

P.O. Box 3090

Carlsbad, NM 88221-3090

U.S. Department of Energy

National TRU Program Office

Carlsbad Area Office

Attn: Mark Matthews

P.O. Box 3090

Carlsbad, NM 88221-3090

U.S. Department of Energy

Office of Geologic Disposal

Yucca Mountain Site Characterization

Project Office

Attn: Linda M. Smith Associate Director RW-20

P.O. Box 98608

Las Vegas, NV 89193-8608

U.S. Environmental Protection Agency

Attn: Reid Rosnick

Mail Code 5303 W

$401 \mathrm{M}$ Street SW

Washington, DC 20460

U.S. Environmental Protection Agency [3]

Office of Radiation/Indoor Air

Criteria and Standards

Attn: Ray Clark William Gunter, Jr.

Lawrence Weinstock

Mail Code 6602J

401 M Street SW

Washington, DC 20460

U.S. Nuclear Regulatory Commission

Advisory Committee on Nuclear Waste [4]

Attn: B. J. Garrick

M. J. Steindler

R. W. Pomeroy

W. J. Hinze

Mail Code T2E26

Washington, DC 20555 
Defense Nuclear Facilities Safety Board Attn: D. Winters

625 Indiana Ave NW

Suite 700

Washington, DC 20004

Nuclear Waste Technical Review Board

Attn: Library [2]

1100 Wilson Blvd

Suite 910

Arlington, VA 22209-2297

Office of Management and Budget

Energy and Science Division

Attn: K. Yuracko

725 17th Street NW

Washington, DC 20503

Yucca Mountain Project Office

U.S. Department of Energy

Attn: Russell Dyer

P.O. Box 98608

Las Vegas, NV 89103

U.S. Nuclear Regulatory Commission [6]

Attn: R. Codell

L. Deering

N. Eisenberg

M. Federline

T. McCartin

J. Randall

Mail Stop 4-H-3

Washington, DC 20555

\section{National Laboratories}

Battelle Pacific Northwest Laboratories

Attn: P.W. Eslinger

MS K2-32

P.O. Box 999

Richland, WA 99352

Idaho National Engineering Laboratory [3]

Attn: H. Loo

R. Klinger

Darryl Siemer

Mail Stop 5108

P.O. Box 1625

Idaho Falls, ID 83403-4000
Idaho National Engineering Laboratory

EG \& G Idaho Inc.

Attn: Sven Magnusson

P.O. Box 1625

Idaho Falls, ID 83415

Corporations/Members of the Public

John F. Ahearne

Executive Director, Sigma Xi

99 Alexander Drive

Research Triangle Park, NC 27709

Center for Nuclear Waste Regulatory Analysis

Southwest Research Institute

Attn: B. Sagar

P.O. Drawer 28510

6220 Culebra Road

San Antonio, TX 78284

R.L. Bras Consulting Engineers

Attn: Rafael L. Bras

44 Percy Road

Lexington, MA 02173

Desert Research Institute - North

Attn: Scott Tyler

P.O. Box 60220

Reno, NV 89506

Desert Research Institute - South

Attn: Jenny Chapman

P.O. Box 19040

Las Vegas, NV 89132-0040

Disposal Safety, Inc

Attn: B. Ross

1660 L. Street NW, Suite 314

Washington, DC 20036

Golder Associates, Inc. [2]

Attn: R. Kossik

I. Miller

4104 148th Avenue NE

Redmond, WA 98052 
GRAM, Inc.

Attn: Krishan Wahi

8500 Menaul Blvd. NE

Suite B-370

Albuquerque, NM 87112

INTERA, Inc.

Attn: W. Nelson

A. E. Van Luik

Valley Bank Building

101 Convention Center Drive

Suite 540

Las Vegas, NV 89109

Raytheon/Environmental Operations [3]

Attn: Dennis Gustafson

Julie Miller

Stuart Rawlinson

222 S. Rainbow, Suite 115

Las Vegas, NV 89128

Reynolds Electrical and Engineering

Company, Inc. [9]

Attn: Dale Daffern

Bob Dodge

Max Dolenc

Brian Dozier

Dudley Emer

Dale Hammermeister

Tom Lindstrom

Greg Shott

Mike Sully

Mail Stop 738

P.O. Box 98521

Las Vegas, NV 89193-8521

Science Applications International

Corporation (SAIC)

Attn: H. R. Pratt

10260 Campus Point Drive

San Diego, CA 92121

Science Applications International

Corporation (SAIC)

Attn: C. G. Pflum

101 Convention Center Drive

Las Vegas, NV 89109
Science Applications International

Corporation (SAIC)

Attn: K. Brinster

2109 Air Park Road SE

Albuquerque, NM 87106

Westinghouse Hanford Co.

Attn: Don Wood

MS HO-33

P.O. Box 1970

Richland, WA 99352

Foreign Agencies

International Atomic Energy Agency [2]

Division of Nuclear Fuel Cycle and Waste

Management

Attn: Shaheed Hossain

Gordon S. Linsley

Wagramerstrasse 5

P.O. Box 100

A-1400 Vienna, AUSTRIA

Atomic Energy of Canada Limited [3]

Whiteshell Research Establishment

Attn: M. E. Stevens

B. W. Goodwin

D. Wushke

Pinawa, Manitoba ROE 1L0, CANADA

Miroslav Kucerka

Botevova 3104

14300 Praha 4

CZECH REPUBLIC

Timo Vieno

Technical Research Centre of Finland (VTT)

Nuclear Energy Laboratory

P.O. Box 208

SF-02151 Espoo, FINLAND

OECD Nuclear Energy Agency [2]

Attn: Claudio Pescatore Jean-Pierre Olivier

Le Seine-Saint Germain

12 Boulevard des Iles

F-92130 Issy-les-Moulineaux, FRANCE 
Gesellschaft für Reaktorsicherheit (GRS)

$\mathrm{MBH}$

Attn: P. Bogorinski

Schwertnergasse 1

D-5000 Köln 1, GERMANY

Netherlands Energy Research Foundation (ECN) [2]

Attn: J. Prij

L.H. Vons

3 Westerduinweg

PO Box 1

NL-1755 ZG Petten, THE NETHERLANDS

CIEMAT Instituto de Tecnología Nuclear [2]

Attn: P. Prado

C. Ruiz

Avenida Complutense, 22

E-28040 Madrid, SPAIN

ENRESA [2]

Attn: P. Carboneras Martinez

Calle Emilio Vargas 7

R-28043 Madrid, SPAIN

Royal Institute of Technology

Automatic Control

Attn: Björn Cronhjort

S-100 44 Stockholm, SWEDEN

Svensk Kärnbränsleforjning $\mathrm{AB}$

Project KBS

Attn: Fred Karlsson

Box 5864

S-102 40 Stockholm, SWEDEN

Swedish Nuclear Fuel and Waste Management Company (SKB) [3]

Attn: Torsten Eng

Nils A. Kjellbert

Tonis Papp

Box 5864

S-102 48 Stockholm, SWEDEN

Swedish Nuclear Power Inspectorate

Statens Kärnkraftinspektion (SKI)

Attn: Johan Andersson

Box 27106

S-102 52 Stockholm, SWEDEN
HSK-Swiss Nuclear Safety Inspectorate

Federal Office of Energy

Attn: J. Vigfusson

CH-5232 Villigen-HSK, SWITZERLAND

Nationale Genossenschaft für die Lagerung

Radioaktiver Abfälle [3]

Attn: C. McCombie

F. Van Dorp

P. Zuidema

Hardstrasse 73

CH-5430 Wettingen, SWITZERLAND

Paul Scherrer Institute [2]

Waste Management Programme

Attn: Richard A. Klos

J. Hadermann

CH-5232 Villigen PSI, SWITZERLAND

AEA Technology

Attn: Dr. C. Peter Jackson

Harwell Laboratory, B424.4

Oxfordshire OX11 0RA

UNITED KINGDOM

Department of the Environment

Her Majesty's Inspectorate of Pollution

Attn: Brian G.J. Thompson

Room A5.33, Romney House

43 Marsham Street

London SW1P 2PY

UNITED KINGDOM

Galson Sciences Ltd.

Attn: Daniel A. Galson

35 Market Place

Oakham, Leicestershire LE15 6DT

UNITED KINGDOM

Intera Information Technologies

Attn: N.A. Chapman

Park View House

14B Burton Street

Melton Mowbray, Leicestershire LE13 1AE

UNITED KINGDOM 
Intera Information Technologies

Attn: David P. Hodgkinson

45 Station Road, Chiltern House

Henley-on-Thames

Oxfordshire RG9 1AT, UNITED KINGDOM

UK Nirex LTD

Attn: Alan J. Hooper

Harwell, Didcot

Oxfordshire OX11 ORH

UNITED KINGDOM

$\begin{array}{lll} & & \\ \text { MS } & \text { ORG } & \\ 0727 & 6622 & \text { M. S. Y. Chu } \\ 0727 & 6622 & \text { J. T. McCord } \\ 0743 & 6907 & \text { M. Harrington } \\ 0743 & 6907 & \text { C. P. Harlan } \\ 0750 & 6118 & \text { H. W. Stockman } \\ 1326 & 6312 & \text { H. A. Dockery } \\ 1326 & 6313 & \text { L. S. Costin } \\ 1328 & 6342 & \text { D. R. Anderson } \\ 1328 & 6342 & \text { M. Marietta } \\ 1330 & 6352 & \text { Nuclear Waste } \\ & & \text { Management Library [2] } \\ 1335 & 6301 & \text { F. W. Bingham } \\ 1335 & 6302 & \text { L. E. Shephard } \\ 1335 & 6303 & \text { W. D.Weart } \\ 1335 & 6305 & \text { S. A. Goldstein } \\ 1335 & 6319 & \text { D. Brosseau } \\ 1337 & 6300 & \text { D. E. Ellis } \\ 1339 & 6903 & \text { G. W. Barr } \\ 1341 & 6306 & \text { A. L. Stevens } \\ 1345 & 6307 & \text { P. A. Davis } \\ 1345 & 6331 & \text { T. A. Baer } \\ 1345 & 6331 & \text { T. Brown } \\ 1345 & 6331 & \text { J. R. Cochran } \\ 1345 & 6331 & \text { S. H. Conrad } \\ 1345 & 6331 & \text { B. Delker } \\ 1345 & 6331 & \text { L. Dubes } \\ 1345 & 6331 & \text { F. A. Durán } \\ 1345 & 6331 & \text { J. Emery } \\ 1345 & 6331 & \text { T. Feeney } \\ 1345 & 6331 & \text { B. Fogleman } \\ 1345 & 6331 & \text { D.P. Gallegos [30] } \\ 1345 & 6331 & \text { R. V. Guzowski } \\ 1345 & 6331 & \text { E. Kalinina } \\ 1345 & 6331 & \text { M. W. Kozak } \\ 1345 & 6331 & \text { G. C. Newman } \\ & & \end{array}$
$1345 \quad 6331$
$1345 \quad 6331$
$1345 \quad 6331$
$1345 \quad 6331$
$1345 \quad 6331$
$1345 \quad 6331$
$1345 \quad 6331$
$1347 \quad 7581$
$1347 \quad 7585$
13513020
L. L. Price
L. Snyder
J. Reitzel
C. D. Updegraff
B. Vocke
E. K. Webb
GCD Records Center/S60
W. B. Cox
K. C. Gaither
N. E. Olague

1 MS 0918 Central Technical Files, 8523-2

5 MS 0899 Technical Library, 7141

1 MS 0619 Technical Publications, 7151

10 MS 1119 Document Processing for DOE/OSTI, 7613-2 